\title{
Kohtuullinen kasvattaja
}

\author{
Kohtuus vaarassa -liike \\ ekososiaalisen sivistyksen \\ tuottajana
}

\begin{abstract}
$y$
Pohjoiskarjalainen Kohtuus vaarassa -kansalaisliike

tavoittelee kulutuskeskeisen ajattelun ja elämäntavan

muutosta. Ryhmä välittää ekososiaalisen sivistyksen sanomaa

seminaareissa, luennoilla ja muissa yleisötapahtumissa.

Tärkeä vaikuttamisen keino ovat myös arkiset kohtaamiset.
\end{abstract}

$\mathbf{y}$

KOHTUUSLIIKE ON YKSI ilmastonmuutosaikakauden verkostomaisista liikkeistä. Se kyseenalaistaa vallitsevan talouskasvuideologian ja tavoittelee kulutuskeskeisen elämän- ja ajattelutavan muutosta. Tarkastelen tässä artikkelissa, kuinka valtakunnallisen liikehdinnän aloittanut pohjoiskarjalainen Kohtuus vaarassa -ryhmä välittää ekososiaalisen sivistyksen arvoja: vastuullisuutta, kohtuullisuutta ja ihmistenvälisyyttä (Salonen \& Bardy 2015).

Ihmiskunta on muuttanut maapallon elinolosuhteita niin paljon, että nykyiselle geologiselle aikakaudelle on ehdotettu uutta nimeä. Elämme antroposeenia, ihmisen aikaa. Aikaamme luonnehtivat paitsi ilmastokriisi myös monet muut ekologiset katastrofit, niiden yhtäaikaisuus ja yhteisvaikutukset: muun muassa kuudes sukupuuttoaalto, typpi- ja fosfori- kiertojen häiriintyminen sekä ympäristön kemikalisoituminen. (Foster, Clark \& York 2010a, 13-14, 18; Steffen ym. 2018, 8252.)

Kohtuus vaarassa -liikkeen ytimessä ovat jatkuvan kasvun kritiikki ja huoli ylikuluttavan elämäntavan vaikutuksista ihmisiin ja koko elonkehään. Ryhmä on valtakunnalliseksi kasvaneen kohtuusliikehdinnän aloittaja. Sille ovat ominaisia verkostomaisuus ja järjestöbyrokratian välttäminen, joita molempia pidetään niin kutsuttujen "uusien liikkeiden” piirteinä (ks. Konttinen \& Peltokoski 2010, 3-5).

Järjestökentällä on 2000-luvun alusta lähtien puhuttu heikentyvästä sitoutumisesta ja jopa niin kutsutusta kevytaktivismista, tempaus- tai tapahtumakohtaisesta osallistumisesta. Sosiaalisen median aktivismin muodot ovat nekin tulleet osaksi 
kansalaisvaikuttajan keinovalikoimaa. (Ilmonen 1998, 31; Kristofferson, White \& Peloza 2014; Stranius 2009; Stranius 2010, 97-99.) Silti suomalaisissa järjestöissä tehdään yhä pitkäjänteistä, sitoutunutta vapaaehtoistyötä. Sen rinnalle on tullut muitakin osallistumisen ja organisoitumisen tapoja.

Kansalaisten tapa osallistua yhteiskunnan toimintaan ja kehittämiseen vaihtelee historiallisen ajanhetken ja paikan mukaan. Aktiivisuus ottaa erilaisia muotoja eri aikoina, ja kansalaiset itse voivat määritellä osallistumistaan eri tavoin. (Bäcklund, Häkli \& Schulman 2017, 5-7.) Perinteisen järjestökentän ulkopuolelle sijoittuvia ryhmittymiä voidaan kutsua esimerkiksi verkostoiksi ja liikkeiksi. Niitä on nimetty myös neljänneksi sektoriksi (Mäenpää \& Faehnle $2021,44)$. Niiden organisoituminen on tyypillisesti keveämpää ja ei-hierarkkista. Samaan luottamustoimeen vuosiksi sitoutumisen asemasta nykypäivän aktiivit hyväksyvät hetkellisyyden ja pitävät sitä jopa suotavana. (Mäenpää, Faehnle \& Schulman 2017, 252-254.)

2000-luvulla kansalaisliikkeitä ja aktivistiverkostoja on muodostunut muun muassa ilmastotoiminnan ympärille. Tällä hetkellä näkyvimpiä ja tunnetuimpia ovat väkivallatonta kansalaistottelemattomuutta keinonaan käyttävä Elokapina (Extinction Rebellion, XR) ja erityisesti ruotsalaiseen Greta Thunbergiin liitetty koululaisten ilmastolakkoliike.

Tieteellistä debattia on käyty siitä, kuinka uusia "uudet liikkeet" ja niiden toimintamuodot lopulta ovat. Myös menneinä vuosikymmeninä ja -satoina liikkeet ovat luoneet uusia merkityksiä, politisoineet ei-poliittisena pidettyä ja toimineet identiteettiliikkeinä. Lisäksi vanhatkin liikkeet uudistuvat. (Ilmonen \& Siisiäinen 1998, 12-13; Ilmonen 1998, 28-30; vrt. Konttinen \& Peltokoski 2010). Jakolinja ei ole yksiselitteinen (ks. Stranius 2010, 85), ja esimerkiksi Kohtuus vaarassa -ryhmä asettuu uuden ja vanhan liikkeen välimaastoon. Sen toimintatavat toisintavat suurelta osin perinteistä järjestötoimintaa mutta ovat osaksi nykyiselle kansalaisaktivismille ominaisia.

Tutkimuskysymykseni on, millainen ekososiaalinen sivistäjä Kohtuus vaarassa -ryhmä on. Tarkastelen, kuinka vastuullisuus, kohtuullisuus ja ihmistenvä- lisyys ilmenevät liikkeen aktiivien haastattelupuheissa, julkaisuissa ja toiminnassa. Lisäksi artikkeli kertoo, miten liike välittää planetaarisen sivistyksen sanomaa.

\section{KOHTUUS JA KOHTUULLISUUS - LIIKE JA IDEOLOGIA}

Kohtuusliike on kulutuskeskeistä ajattelun- ja elämäntapaa haastava kansalaisliike, joka syntyi vuosien 2008-2009 tienoilla Pohjois-Karjalan uraanikaivosten vastaisen kansalaisliikkeen luomalle pohjalle (Lehtinen 2019, 237). Sitä kutsuttiin pitkään Kohtuusliikkeeksi, mutta arkisessa kielenkäytössä sekoittuivat liikkeen ja sen joka toinen vuosi järjestämän seminaarin nimi, "Kohtuus vaarassa”. Kun liike laajeni valtakunnalliseksi 2010-luvun puolivälin jälkeen, päätettiin selkeyden vuoksi ottaa Pohjois-Karjalassa käyttöön jo tutuksi tullut muoto "Kohtuus vaarassa". Kohtuusliike-muotoinen kirjoitusasu jätettiin yleisnimeksi, joka tosin on nyt muotoutumassa eteläsuomalaisten toimijoiden omaksi erisnimeksi Kohtuusliike-verkkosivuston vuoksi. Käytän tässä artikkelissa Kohtuus vaarassa -erisnimeä paikallisesta toiminnasta ja pienellä alkukirjaimella kirjoitettua 'kohtuusliikettä' valtakunnallisesta kohtuusliikehdinnästä.

Kohtuus vaarassa -ryhmän ajama muutos on laaja-alainen. Ryhmä ei rajaudu ainoastaan ympäristöliikkeeksi tai talouskritiikin esittäjäksi, vaan ekologisesti ja sosiaalisesti kestävämpää elämäntapaa tarkastellaan liikkeen piirissä useista näkökulmista (Lehtinen 2014, 71). Ominaista sille on myös kulttuurin ja taiteen yhdistäminen liikkeelle tärkeisiin teemoihin.

Ryhmän historiaa on käsitelty ainakin kahdessa artikkelissa. Liikkeen perustajiin kuuluva Markku Aho laati vuonna 2015 julkaistuun Onnen aikoja rajallisella planeetalla-artikkelikokoelmaan lyhyen tekstin, jossa hän kävi läpi Kohtuus vaarassa -liikkeen varhaisvaiheita ja kirjoittamishetkellä ajankohtaista toimintaa (Aho 2015). Kirjoittaja, kansalaisaktivisti ja sosiologi Marko Ulvilan (2019) koonti Elonkehässä tarkastelee degrowth-liikkeen syntyä. Artikkelissaan Ulvila esittelee myös "kohtuuden käsitteen ympärille" muotoutunutta liikettä. Hän paikantaa liikkeen alkuhetkeksi Ahon, teatteriohjaaja Hanna Kirjavaisen 


\section{VAURAUS TULISI YMMÄRT $\dddot{A} \ddot{A}$}

\author{
MYÖS EI-MATERIAALISENA \\ ELÄMÄN RIKKAUTENA.
}

ja pappi, kansalaisaktivisti Pauliina Kainulaisen laatiman mielipidetekstin Helsingin Sanomissa keväällä 2009. Kirjoittajat peräänkuuluttivat kohtuuden kulttuuria, jossa "panostetaan tosissaan energiansäästöön, energiatehokkuuteen ja uusiutuvien energialähteiden kehittämiseen”. (Ulvila 2019, 24.)

Kohtuus vaarassa -ryhmän toiminnan varsinainen lähtölaukaus oli Kohtuus vaarassa -seminaari syksyllä 2009 (Aho 2015; Ulvila 2019). Tapahtuma oli vastatapahtuma Koli forum -tilaisuudelle, luonnonvara- ja ympäristöalan päättäjien ja asiantuntijoiden kokoontumiselle. Seminaareja on pidetty seitsemän, viimeisin lokakuussa 2019. Lisäksi on järjestetty lukuisia muita tilaisuuksia, kuten Kohtuus-klubeja, yleisöluentoja, retkiä ja tempauksia. Luennoijina ja työpajojen vetäjinä on ollut eri alojen tutkijoita, aktivisteja ja taiteilijoita, joita yhdistää liikkeen arvojen suunnassa toimiminen. Tapahtumat ovat tavoittaneet yli 500 henkilöä (Aho 2019, 168). Kohtuus vaarassa -ryhmää voi pitää tärkeänä ympäristökasvattajana jäsenilleen ja tapahtumien osallistujille (ks. Silva \& Laird 2017, 176).

Eri paikkakuntien kohtuusryhmät aktiiveineen ovat kiinnostaneet tutkielmien tekijöitä ja tutkijoita. Teemu Kuosmasen (2010) sosiologian pro gradu -tutkielmassa haastateltiin kohtuullistajiksi nimettyjä henkilöitä, joiden joukossa oli myös yksi Kohtuus vaarassa -toimija. Tutkielmassa tarkasteltiin kohtuullistajien elämää kiirekulttuurin läpäisemässä yhteiskunnassa. Taina Linnan (2017) yhteiskuntapolitiikan pro gradu -tutkielma kartoitti suomalaista degrowth-liikehdintää ja degrowth-aktivistien kasvukriittistä ajattelua. Tässäkin yksi haastateltava oli pohjoiskarjalainen kohtuusaktiivi. Ryhmän kotisivujen julkaisuja on analysoitu sosiologi Satu Husson (2017) tutkimuksessa, jossa tarkasteltiin talouskasvua ja kulutuskulttuuria kritisoivien liikkeiden näkemyksiä yhteiskunnallisista muutostapeista matkalla kohti kestävää kulttuuria. Tutkimuskirjallisuudessa
Kohtuus vaarassa -ryhmä on ollut esillä myös kohtuustoimija, professori Ari Lehtisen (esim. 2014; 2019) julkaisuissa muun muassa ympäristötoimintatutkimuksen kenttänä.

'Kohtuuden' asemasta käytetään useimmiten kasvunpakosta luopumiseen ja vähentämiseen viittaavaa käsitettä degrowth, joka tuli tutuksi suuremmalle yleisölle 2000-luvun alussa. Degrowth-ajattelun nähdään yhdistävän monia kriittisiä näkökantoja. Sen lähteiksi on nimetty ekologinen huoli, edistys- ja kehityskritiikki, ylenpalttisen kuluttamisen ja hyvinvoinnin välisen yhteyden purkaminen, ekologisen taloustieteen opit sekä demokratian ja sosiaalisen oikeudenmukaisuuden edistäminen. Muutosvaateiksi on mainittu ihmissuhteiden laajentaminen, syvempi demokratia, ekosysteemien suojelu ja varallisuuden tasaisempi jakautuminen globaalisti. (Demaria ym. 2013, 191-192, 195-196; Jarvis 2017; Trainer 2015, 58.)

Suomessa tunnetaan myös käsite 'kohtuutalous', jota voi pitää degrowth-termin suomennoksena (Latva-Pukkila 2015; Lehtinen 2019, 237; ks. myös Finto). 'Kohtuudelle' läheisiä käsitteitä ja elämäntapoja ovat lisäksi downshifting ja simple living (Alexander \& Ussher 2012) sekä slow living (Ioncică \& Petrescu 2016). Vaikka kohtuuden määrittely on avointa ja liikkuvaa, tärkeää on ensinnäkin eronteko teknologiavetoiseen, "vihreää" tai "kestävää" kasvua tavoittelevaan ajatteluun ja vaikuttamistyöhön (ks. Foster, Clark \& York 2010b, 153; Martin, Maris \& Simberloff 2016). Toiseksi, kuten Sanna Hussokin (2017, 170) toteaa, kohtuusliike ei rajaudu talouden kysymyksiin, vaan siinä tavoitellaan kohtuutta useammilla kentillä, ja kohtuuden kysymykset nähdään laajoina yhteiskunnallisina kysymyksinä.

Ekososiaalisen sivistyksen käsitettä on muotoillut erityisesti kestävyystutkija Arto O. Salonen. Kasvatustieteilijä Marjatta Bardy ja Salonen ovat ovat nimenneet ekososiaalisen sivistyksen ydinarvoiksi vastuullisuuden, kohtuullisuuden ja ihmistenvälisyyden (taulukko 1). Keskeistä on ymmärrys maapallon rajallisuudesta ja sosiaalisesta oikeudenmukaisuudesta. (Salonen \& Bardy 2015.)

Vastuullisuudella Salonen ja Bardy (2015) tarkoittavat maailmankansalaisuutta, vastuun kantamista omaa lähipiiriä laajemmasta joukosta. Globaali 


\begin{tabular}{|l|l|l|}
\hline Vastuullisuus & \multicolumn{2}{l|}{ Kohtuullisuus } \\
\hline $\begin{array}{l}\text { Eettinen huolenpito } \\
\text { - globaali ulottuvuus } \\
\text { suklinen ulottuvuus tuleviin }\end{array}$ & $\begin{array}{l}\text { Minkä verran on riittävästi } \\
\text {-pohdinta } \\
\text { - kuluttaminen tarpeen, ei halujen } \\
\text { ohjaamana }\end{array}$ & $\begin{array}{l}\text { Mahdollisuus liittyä yhteisöihin, } \\
\text { ihmissuhteet }\end{array}$ \\
\hline $\begin{array}{l}\text { Muiden näkökulmasta } \\
\text { katsominen }\end{array}$ & $\begin{array}{l}\text { Luonnonvarojen kohtuullinen } \\
\text { käyttö }\end{array}$ & Solidaarisuus \\
\hline Huolenpito luonnosta & $\begin{array}{l}\text { Ei-materiaalisen vaurauden } \\
\text { tavoittelu }\end{array}$ & Yhdessä tekeminen \\
\hline Sosiaalinen vastuu & & \\
\hline
\end{tabular}

Taulukko 1. Ekososiaalisen sivistyksen keskeiset piirteet (Salonen \& Bardy 2015, 8-10).

talous yhdistää maat, kansat ja ihmiset. Vastuullisuuden piiriin sopii luonnonvarojen käyttö, mutta samalla tulee huolehtia luonnosta ja siitä, että tulevilla sukupolvilla on samat tai paremmat toimintamahdollisuudet kuin meillä nyt. Kohtuullisuus, pidättäytyminen materiaalisesta ylivauraudesta, on tämän tavoitteen saavuttamisessa avainasemassa. Vauraus tulisi ymmärtää laajemmin, myös ei-materiaalisena elämän rikkautena. Luonnonvarojen hyödyntämisen pitää pysyä kohtuuden rajoissa, ja kulutuksen tulee perustua tarpeeseen, ei ainoastaan mielihyvän tavoitteluun. (Salonen \& Bardy 2015, 8-9.)

Ihmistenvälisyys tarkoittaa solidaarisuutta, mahdollisuutta liittyä yhteisöihin ja tulla niissä hyväksytyksi. Ihmistenvälisyyteen liittyy ekologinen näkökulma: "ystävyyden ja osallisuuden toteutuessa omistamisen merkitys vähenee". (Salonen \& Bardy 2015, 9-10.) Samoin sosiaalimaantieteilijä Helen Jarvis $(2017,270)$ näkee yhteenkuuluvuuden, jakamisen ja yhteishengen yksilökeskeisen (yli)kulutuksen haastajina.

Relationaalisen ihmiskäsityksen kehyksestä käsin tarkasteltuna ihminen ei ole erillinen yksilö vaan osa luontoa. Kiinnostuksen kohteena ovat laajat suhteiden verkostot, mukaan lukien kaukaiset luonnonoliot ja tulevat sukupolvet. (Hirvilammi 2015, 80.) Ekososiaalisen sivistyksen yhteydessä puhutaan hyvin samaan tapaan 'planetaarisesta sivistyksestä': yksilö ymmärtää ja huomioi toimintansa seuraukset laajalla ajallisella jatkumolla paikallisesti ja globaalisti, jopa yli lajirajojen. Hän kantaa vastuuta plane- taarisessa kehyksessä ja ymmärtää menneisyyden, nykyisyyden ja tulevaisuuden välisen ajallisen sillan sekä huomioi oman toimintansa globaalit seuraukset, paikallisia vaikutuksia unohtamatta. (Joutsenvirta \& Salonen 2020, 108-109; Salonen 2020).

Monien samanaikaisten ekokriisien aikakaudella tarvitaan uudistavaa ajattelua ja oppimista sekä uudenlaisia kasvattajia, myös aikuiskasvattajia (ks. Heikkinen \& Harju 2016; Sumner 2003). Muun muassa kasvatusfilosofi Veli-Matti Värrin (2011, 28, 32) mukaan kasvatuksessa tulee haastaa vallitseva talouskasvu- ja kilpailuideologia. Uudenlaisten arvojen omaksuminen edellyttää asenteiden muuttamista, mikä tarkoittaa yksilön syvällistä uudistumista. Ekososiaalinen sivistyminen vaatii transformatiivista, uudistavaa oppimista (ks. Mezirow 2009).

\section{TUTKIMUKSEN TOTEUTUS}

Tutkimuksen aineisto on yhdistelmä tuotettuja ja valmiita aineistoja: haastatteluja, painettuja julkaisuja ja havainnointia. Haastatteluaineisto on ensisijaisin. Haastattelin seitsemää pohjoiskarjalaista kohtuusaktiivia. Ensimmäisen haastattelun tein helmikuussa 2019 ja viisi muuta saman vuoden elo-lokakuussa. Ensimmäinen haastattelu oli parihaastattelu, muut yksilöhaastatteluja. Haastattelujen kestot vaihtelivat noin tunnista puoleentoista tuntiin. Niitä ohjasi teemoittainen haastattelurunko. Keskustelimme haastateltavan taustasta, syistä liittyä liikkeeseen ja oppimisen kokemuksista liikkeessä. Kysyin myös näkemyk- 


\section{RYHMÄN YDINTOIMIJOISTA}

\section{MONILLA ON PITKÄ}

\section{KOKEMUS KANSALAIS- JA \\ JÄRJESTÖTOIMINNASTA.}

siä kohtuuden määrittelystä, kohtuullisemmasta elämäntavasta ja kohtuusliikkeen vaikuttavuudesta.

Toissijainen, painettu aineisto muodostuu julisteen tapaan jaetusta 10 kohtuullista vaatimusta -julkilausumasta (2009), Kohtuusmanifesti-pienpainatteesta (2011) ja kahdesta liikkeen laatimasta artikkelikokoelmasta: Onnen aikoja rajallisella planeetalla (toim. Linjama \& Kainulainen 2015) ja Kohtuuspamfletti - elonkirjo edellä (toim. Linjama, Aho, Kainulainen \& Simola 2019).

Tukeudun tulkinnoissani myös havaintoihini ja kokemuksiini liikkeen jäsenenä. Havainnointiaineisto on tausta-aineistona. Havainnoin ryhmän tapahtumia ja kokouksia noin puolentoista vuoden ajan kokouksissa, tapahtumissa ja retkillä vuodenvaihteesta 2018-2019 kesään 2020 asti. Osallistuin luentotapahtumiin, Kohtuus vaarassa -seminaariin, luontoretkille ja suunnittelukokouksiin. Havainnointi oli osallistuvaa, ja tein lyhyitä muistiinpanoja laajojen kenttäpäiväkirjojen asemesta. Tutkimuseettisistä syistä muistiinpanoni eivät ole yksityiskohtaisia, enkä ole valokuvannut tiettyjä henkilöitä vaan esimerkiksi tapahtumapaikkaa tai laajemmin yleisöä. Tarkentavia tietoja muun muassa tapahtumista olen hakenut sähköisistä julkaisuista: Kohtuus vaarassa -sivulta yhteisöpalvelu Facebookista, liikkeen verkkosivulta (http://www.kohtuusvaarassa.com) sekä luento- ja tapahtumatallenteista ryhmän YouTube-kanavalta.

Kohtuus vaarassa -liikkeen ydin koostuu noin kymmenestä aktiivista, jotka osallistuvat säännöllisesti kokouksiin ja tapahtumiin. Heitä yhdistää kouluttautuneisuus, monia akateeminen tausta, ja karkeasti arvioiden noin puolet ydinryhmän aktiiveista on eläkeikää lähestyviä tai eläköityneitä. Seitsemän haastateltua edustavat tätä ydinjoukkoa. Osa heistä on ollut mukana liikkeessä alusta saakka, osa lyhyemmän aikaa.
Kysyin haastatteluissa motiiveja liikkeeseen liittymiselle, ja muutamat muistelivat heräämistään ympäristökysymyksiin huomattavan kauan aikaa sitten. Ryhmän ydintoimijoista monilla onkin pitkä kokemus kansalais- ja järjestötoiminnasta, ja heistä osa on ollut mukana suomalaisessa ympäristöliikkeessä vuosikymmeniä, niin vakiintuneissa järjestöissä (ks. Stranius 2010, 84) kuin ympäristökamppailuiden aktivisteina. Osallistujajoukon pienuuden vuoksi en kuvaa artikkelissa haastateltujen taustatietoja tarkemmin.

Ryhmän tiiviyden vuoksi kiinnitän muutoinkin erityistä huomiota haastattelujen anonymisointiin. En erottele haastateltavia edes tunnuksin, kuten $\mathrm{H1}$ tai $\mathrm{H} 2$ vaan käytän kaikkien aineistonäytteiden kohdalla merkintää ' $H$ ' haastateltavan puheenvuoron edellä, jotta eri näytteitä ei voitaisi yhdistää samaan puhujaan. 'K' viittaa minuun haastattelijana: kysymys. Haastatteluaineiston sitaateista on poistettu murteellisuuksia, ja puhetta on tehty luettavammaksi poistamalla muun muassa äännähdyksiä ja toistoja. Tämä myös vaikeuttaa haastateltavan tunnistamista puheen piirteiden perusteella.

Erityinen eettinen kysymys koskee omaa paikkaani liikkeessä. Ryhmän jäsen olen ollut yli 10 vuotta, vuonna 2009 järjestetystä ensimmäisestä Kohtuus vaarassa -seminaarista alkaen. Olen tullut tutuksi ainakin jollakin tapaa kaikkien haastattelemieni henkilöiden kanssa, ja muutamien kanssa olemme tunteneet pitkään. Tuttuus ja asemani liikkeen jäsenenä auttoivat minua "pääsemään sisään" kentälle. Tiedän ja ymmärrän asioita, joita ulkopuolisen olisi vaikea oppia ja omaksua nopeasti. (Ks. Tolonen \& Palmu 2008, 96-99; Tracy 2010, 843.)

Koin oloni tervetulleeksi pohjoiskarjalaisten kohtuusaktiivien tapahtumiin ja retkille myös tutkijan roolissa. Tämä ei tietenkään tarkoita, etteivätkö jotkut toimijat saattaneet kokea läsnäoloani ja roolini osittaista vaihtumista hankalana. Haastatteluissa esitettiin myös joitakin kriittisiä ajatuksia liikkeestä, mitä pidän luottamuksen osoituksena. Raportoinnissa olen pyrkinyt avoimuuteen, ja tuon esiin muun muassa kohtuustoiminnan muotoja koskevaa kritiikkiä.

Osallistuvana havainnoijana olen arvioinut rooliani: esimerkiksi tilaisuuksien tauoilla kanssani 
käytyjä vapaamuotoisempia keskusteluja en ole tallentanut millään tavalla, mutta nekin vaikuttavat tulkintoihini, halusin tai en. Tiedostan myös sen mahdollisuuden, että olen herättänyt liikkeessä pohdintaa sen kasvattavasta tai sivistyksellisestä roolista, kun olen kertonut tutkimuksestani aktiiveille (ks. Metsola 2016, 197) ja vieläpä julkaissut aiheesta kirjoituksen (Laakkonen 2019). Kenties he havahtuivat näkemään itsensä uudessa valossa, "ekosivistäjinä", kun heidät näin määriteltiin?

Analyysini on teorialähtöistä laadullista sisällönanalyysia (Schreier 2014; Tuomi \& Sarajärvi 2017). Toisin kuin teemoittelussa (Juhila 2020b), tässä analyysissa kategoriat olivat ennalta määritellyt. Salosen ja Bardyn (2015) kuvaus ekososiaalisen sivistyksen ydinarvoista (taulukko 1) on tutkimuksessani linssi, jonka läpi tarkastelen Kohtuus vaarassa -ryhmän toimintaa kasvatuksellisesta näkökulmasta. Teorialähtöisen analyysin valinnalle on kolme keskeistä syytä: Ensinnäkin pidän Salosen ja Bardyn artikkelia tärkeänä esityksenä ekososiaalisen sivistyksen olemuksesta. Toiseksi halusin kokeilla kyseisen, melko teoreettisen jaottelun selitysvoimaa empiirisellä aineistolla. Kiinnostukseni tarkempaan analyysiin heräsi laatiessani yleistajuista tekstiä (Laakkonen 2019), jossa totesin liikkeen olevan ekososiaalinen sivistäjä. Kolmanneksi teoreettisen työkalun käyttö ohjasi aineiston luentaa ja analyysia, mikä lisäsi tekemieni tulkintojen objektiivisuutta ja auttoi päätelmien kriittisessä tarkastelussa.

Haastatteluaineiston analyysi alkoi laadulliselle sisällönanalyysille tyypilliseen tapaan aineiston lukemisella ja koodaamisella (ks. Juhila 2020a; Vuori 2020), tässä tapauksessa ennalta tiedettyjen koodien avulla: merkitsin aineistoon katkelmat, joissa tulkintani mukaan kuvataan ekososiaalisen sivistyksen keskeisiä piirteitä. Käytännössä jaottelu ei ole selvärajaista, vaan eri piirteiden erotteleminen toisistaan on tarpeen vain analyysin kannalta. Koodaaminenkin oli jo analyyttista työskentelyä, ja tulkintojen tekeminen alkoi tässä vaiheessa. Toissijaista aineistoa eli liikkeen julkaisuja ja verkossa olevia tapahtumatallenteita en koodannut. Niiden lukeminen ja katseleminen vuorottelivat haastatteluaineiston analyysin kanssa: julkaisuja ja tallentei- ta käytin vahvistaakseni - ja myös horjuttaakseni haastatteluista tekemiäni tulkintoja. Kolmas aineisto, havainnointiaineisto, on toiminut ymmärrystäni syventävänä tausta-aineistoina läpi koko analyysi- ja tulkintaprosessin.

\section{TULOKSET}

Etenen tulosluvuissa esitellen vastuullisuuden, kohtuullisuuden ja ihmistenvälisyyden kuvauksia aineistoissa. Näihin kokonaisuuksiin sisältyvät ekososiaalisen sivistyksen keskeiset piirteet (taulukko 1).

\section{Vastuullisuus}

Kohtuus vaarassa -ryhmässä pohditaan toistuvasti maapallon rajallisten resurssien epätasapuolista jakautumista sekä ylikulutuksen aiheuttamia globaaleja haittoja. Vastuunkanto ei siis rajoitu perinteiseen luonnonsuojeluun, vaan esillä ovat laajasti erilaiset näkökulmat (Laakkonen 2019, 190). Vuoden 2011 eduskuntavaalien alla laadittu Kohtuusmanifesti (2011) tarjoaa alaotsikkonsa mukaan "aineksia vastuulliseen hallitusohjelmaan”. Käsittelyssä ovat muun muassa turpeenpoltto, muovijäte, ydinvoima ja eläinperäinen ruoka. Yhdistävänä teemana kulkee läpi koko manifestin talous, kasvun pakko.

Haastattelemani aktiivi sanoi, tosin mahdollisesti hieman humoristisesti, että liikkeen tavoitteena on koko länsimaisen elämäntavan muutos. Seminaareissa ja muissa tilaisuuksissa kerrotaan, kuinka kulutuskeskeinen elämäntapa nielee luonnonvaroja, ja tuotteet tuotetaan olosuhteissa, joista kuluttajan on vaikea saada tietoa. Yhteisöpalvelu Facebookin julkaisuissa otetaan kantaa aseteollisuuden ilmastojalanjälkeen ja kerrotaan näin rauhantyön ja kohtuuden linkittymisestä toisiinsa. Ympäristö-, ihmisoikeus- ja oikeudenmukaisuuskysymykset ja monet muut kysymykset liittyvät kaikki toisiinsa kompleksisiksi ongelmavyyhdeiksi.

Esimerkiksi huhtikuussa 2018 järjestetyssä "Vähennetään vaatteita!" -tapahtumassa yhdistyivät monet teemat. Illan asiantuntijapuheenvuoroissa käsiteltiin Facebook-tapahtuman kuvauksen mukaan vaatetuotannon epäekologisuutta ja epäeettisyyttä; 


\section{RYHMÄN JÄSENET NÄKEVÄT}

\section{KOHTUUSTOIMINNAN}

TAVOITTEET LAAJOINA.

vaatteiden ylenmääräistä kuluttamista ja toisaalta kampanjoita, jotka pyrkivät korjaamaan näitä epäkohtia. Lopuksi osallistujat saivat neuvoja vaatteiden kierrätyksestä, ja työpajaosuudessa muun muassa korjattiin osanottajien tilaisuuteen tuomia vaatteita. Tapahtumassa sosiaalinen oikeudenmukaisuus linkitettiin ekologisiin ja taloudellisiin kysymyksiin.

Toisen esimerkin tarjoaa liikenteen sähköistämisestä käyty keskustelu. Sähköautojen pienet ajonaikaiset päästöt ovat toki Kohtuus vaarassa -toimijoiden mielestä merkittävä etu, mutta asiassa nähdään myös ongelmia. Kenties liikkeen taustan takia, Enon uraanikaivostaisteluista kummuten, aktiivit esittävät kriittisiä puheenvuoroja akkumetallien hankinnasta ja kierrätyksestä. Arvostelua herättää myös ekologisemman tai "ekologisemman" kuluttamisen tukeminen. Kuten haastattelemani aktiivi napautti, "polttomoottoriautot vaihtuu sähköautoiks" eli kulutusta ei tarvitsisi vähentää, vain suunnata uudelleen.

Kohtuus vaarassa -tapahtumissa monimutkaisten pulmien perimmäisiä syitä on haettu niin fossiilitaloudesta eli öljyyn perustuvan taloutemme rakenteista kuin ajattelutavastamme. Etenkin ryhmää koordinoiva Pauliina Kainulainen on tuonut liikkeeseen suomalaisugrilaiseksi nimettyä ajattelua. Tämä tarkoittaa muinaisen maailmankuvan ja ajattelutavan muistamista ja elvyttämistä, itämerensuomalaisen metsästäjä-keräilijäkulttuurin henkisen perinnön kunnioittamista ja siitä oppimista, kuten luontoyhteyden vaalimista. Hänen mukaansa luonnon ymmärtäminen pyhänä palauttaa rajan tajun, kohtuullisuuden. Ihminen ottaisi luonnosta tällöin vain tarpeen mukaan ja käyttäisi ottamansa "tarkasti ja viisaasti”. (Kainulainen 2019, 100.)

Tiedon lähteitä ovat pohtineet muutkin puhujat Kohtuus-tilaisuuksissa, ja itämerensuomalainen näkökulma on tullut esiin myös filosofi Tere Vadénin esityksissä Kohtuus vaarassa -seminaareissa. Esimerkiksi vuoden 2019 seminaarissa etsittiin juurisyytä:
Suomalaisessa uskomusperinteessä synty kuvaa jonkin asian alkuperän, ja parantavan henkilön tuli tietää taudin synty saadakseen sen karkotettua. Jos kohtuuttomuuden synty olisi tiedossa, voitaisiin kyseinen "tauti" hävittää.

Laajaa vastuullisuutta ilmentää Kohtuus vaarassa -liikkeessä syvä luontoyhteys: henkisempää tai hengellisempää näkökulmaa luonnosta huolehtimiseen ei sivuuteta, ja syväekologiset ajatukset ovat toistuvasti esillä. Luontoyhteyteen liittyviä teemoja ovat käsitelleet Kohtuus vaarassa -tapahtumissa Kainulaisen ohella muun muassa ekopsykologit, kuten Irma Heiskanen. Vuoden 2019 Kohtuus vaarassa -seminaarissa hänen vetämässään työpajassa kuviteltiin "biotopiaa". Työpajan alaotsikko oli "unelma eri lajien välisen syvällisen yhteisöllisyyden tiedostamisesta”, ja menetelmänä oli elämyksellinen luontoretki. Työpajan anti purettiin perinteisen esityksen asemesta liikkeen ja runollisen ilmaisun avulla.

\section{Kohtuullisuus}

Haastattelemieni pitkään liikkeessä mukana olleiden kohtuusaktiivien mukaan Suomessa ei juuri puhuttukaan degrowth-ideologiasta, kun kohtuusliikettä perustettiin. Heidän näkemyksensä mukaan kohtuusliike ei siten ole degrowth-ideologian synnyttämä, vaan suomalaisesta liikehdinnästä voitaisiin ajatella jopa päinvastoin. Kaksi aktiivia muisteli kohdanneensa degrowth-käsitteen vasta sen jälkeen, kun kohtuustoiminta oli jo käynnistynyt ensimmäisen, vuoden 2009, Kohtuus vaarassa -seminaarin myötä. Suomalaisen degrowth-liikkeen historiaa kartoittanut yhteiskuntatieteilijä Antti Alaja $(2011,23)$ mainitsee kotimaisen keskustelun aloittajina Timo Järvensivun ja Paavo Järvensivun degrowth.fi-blogin perustamisen vuonna 2010, samana vuotena järjestetyt konferenssit ja degrowth-tapahtumat sekä Marko Ulvilan ja Jarna Pasasen teoksen Vihreä uusjako, sekin samalta vuodelta.

Tässä artikkelissa olen päätynyt pitämään pohjoiskarjalaista kohtuusryhmää laajana elämän- ja ajattelutavan muutosta hakevana liikkeenä, kuten haastatteluissakin linjattiin. Kohtuus vaarassa -ryhmässä ei käytetä degrowth-termiä yhtä paljon kuin 
vaikkapa Kohtuusliikkeen verkkosivustolla (https:// kohtuusliike.fi/), jossa 'kohtuutta' määritelläänkin kohtuutalouden kautta, mainiten 'kohtuutalous' ja 'degrowth' synonyymeiksi. Myös Linna (2017) on tarkastellut Kohtuus vaarassa -ryhmää pro gradussaan osana degrowth-liikettä. Husso $(2017,169)$ puolestaan kirjoittaa kohtuusliikehdinnästä ja kohtuusdiskurssista ja muistuttaa, että kasvukritiikistä ei aina käytetä termiä degrowth, ”vaan käytetään myös käsitteitä onnellisuustalous ja kohtuullistaminen”.

Ryhmän jäsenet näkevät kohtuustoiminnan tavoitteet laajoina. "Maapallo pelastuu. Ihmisten olo helpottuu. Ihmiset löytää sisältöö elämään. Riittääkö nämä?” vastasi eräs haastateltava nauraen, kun kysyin ryhmän tavoitteista. Toista haastateltavaa pyysin selittämään, mitä kohtuullisuus on. Hän mainitsi paitsi luonnonvarojen kohtuullisen käytön, myös muiden ihmisten hyvinvoinnin huomioimisen. Vastausta voi lukea osuvana kuvauksena planetaarisesta sivistyksestä ja siitä, kuinka kohtuullisuus ja vastuullisuus kietoutuvat toisiinsa:

H: "Kohtuullisuutta siinä että ei käytetä liikaa maapallon luonnonvaroja, resursseja, vaan yritetään elää sillä tavalla, että, että ei [painokkaasti] kohtuuttomasti rasiteta meidän maapalloa."

K: "Eli se liittyy siihen luonnonvarojen -"

H: ”Joo, mulle se liittyy siihen hyvin paljon joo. Ja tota. Ehkä myöskin [--], et ei semmosta niinkun talouskasvun, kun mä kuitenkin liitän siihen semmosen kilpailun ja siihen että semmosen ajattelun, että minä, ja minun ego, minun hyvinvointini, muiden ihmisten hyvinvoinnin, se on niinku tärkeämpää. [--] mä käsitän sen, et kohtuullisuus myöski on sitä että verkostoidutaan, otetaan muitakin ihmisiä niinkun elämässä, että ei, ei pelkästään minä vaan myös, myös muut. Et semmonen ajattelu."

10 kohtuullista vaatimusta -teeseissä määritellään kohtuus tiiviisti: "Kohtuus arvoonsa. Se on vapautta kulutusriippuvuuksista." Laajemmin ja luovemmin kohtuuden olemusta on pohdittu muun muassa Kohtuuden joulun julistuksissa, kulutuskriittisissä joulun toivotuksissa. Niitä on luettu muun muassa Joen- suun keskustassa joulun alla sekä julkaistu tallenteina YouTubessa. Kirjoittajiksi ja esittäjiksi on kutsuttu paikallisesti ja valtakunnallisesti tunnettuja henkilöitä. (Laakkonen 2019, 191.)

Kohtuuden olemusta ja myös siihen liitettyjä kielteisiä mielikuvia pohditaan liikkeen kokoontumisissa toistuvasti. Siitä on kirjoitettu, lausuttu ja laulettu koko toiminnan ajan. Kohtuudesta vitsaillaankin; esimerkiksi kohtuuden konnotaatioista kohtuulliseen alkoholinkäyttöön, mutta myös vakavammalla pohjavireellä, jolloin esiin tulevat oletettujen "toisten" oletetut ajatukset kohtuudesta niukkuutena. Sanaa niukkuus ei juuri käytetäkään Kohtuus vaarassa -liikkeen piirissä. Valinta on tietoinen. Päinvastoin liikkeen toimijat vakuuttavat, että kohtuullinen elämä sisältää aikaa nautiskelulle, kuten kulttuurielämyksille (ks. Joutsenvirta \& Salonen 2020,91-95). Yksi haastateltava mietti, kuinka lyhytaikaista on ilo uudesta vaatteesta tai matkasta "aurinkorannalle". Sitä vastoin pidempään kestää "tyytyväisyys ja ilo", joita saa "empatiakyvystä, toisten huomioimisesta ja, ja siitä että on mahollisuus päästä luontoon”. Hän lisäsi listaan vielä musiikkiharrastukset: konserteissa käymisen ja yhdessä laulamisen.

Eräs aktiivi painotti, että meidän tulisi ostaa asioita tarpeiden mukaan. Hän sanoi mainostamisen olevan "ylikulutuksen mainostamista". Hän ei ole koskaan ostanut yhtäkään muovikassia; sellainen ei ole tullut hänelle mieleenkään, ovathan kestokassit olemassa. Kysyin, onko tämä asennoituminen jo aiemmin, "ennen kohtuusliikettä", omaksuttua. Haastateltava kuvasi lapsuudenkotinsa tarjonneen kaiken tarpeellisen, vaikka he elivät "pienellä rahalla”. Hän myös valotti kulutuskritiikkinsä olemusta:

K: " [--] Et sä tavallaan elit [hymyillen] semmosta kohtuullista elämää jo ennen kohtuusliikettä?"

H: ”Joo siis, [--] mä en oo niinku ymmärtäny sitä, että miks pitäs kuluttaa. Siis. Kuluu, kuluuhan, tavarat kuluu ja vaatteet kuluu ja sitten kun ne ei enää palvele sitä tehtävää, mitä [nauraen] ne on, niin sitten ostetaan uutta ja. [--] mä niinku, se on musta niin abstrakti käsite, et miks pitää kuluttaa. Ja sitten vedotaan että pitää kuluttaa ja [--] talouden kasvaa ja pyöriä, että. Että saatas hyvinvointia 
ja tämmöstä ja musta se kuluttaminen niinkun ei oo hyvinvointia [--] se on ihan minussa sisässä oleva juttu, [--] siis mä [todeten] tarvitaan tarpeitten mukaan."

Jatkuvan kasvun ideologian kritiikki on keskeistä Kohtuus vaarassa -liikkeessä: aihe toistuu aktiivien puheissa ja ryhmän julkaisuissa; vaihtoehtoisista talousmalleista on kuultu tilaisuuksissa asiantuntijaesityksiä. Vaikka kaikki ryhmän jäsenet eivät ole perehtyneitä talouskysymyksiin, he tuntuvat jakavan melko yhteneväisen käsityksen siitä, että talouden tulisi toimia toisin. Eräs haastateltava tiivisti näkemyksensä vallitsevan talousajattelun ja kohtuusideologian ristiriidasta huomauttamalla, että "meidän talous perustuu siihen, että ylikäytetään luonnonvaroja ja se ei ole kestävällä pohjalla ollenkaan”.

Elämme kulutuskulttuurissa ja altistumme sen sanomalle väistämättä (Usher 2008, 32). Kohtuus vaarassa -liikkeen yksi vaatimus onkin mainonnan rajoittaminen. Se on yksi kymmenestä Kohtuullisesta vaatimuksesta, ja perusteluna esitetään, että mainonta "luo keinotekoisia tarpeita". Samaisissa vaatimuksissa esitetään "yhteisiä sitovia rajoituksia kulutukseen" ja todetaan, että "kulutusta on supistettava oikeudenmukaisesti ja hallitusti". Kohtuusmanifestissa käytetään termiä lööppisaaste ja perätään oikeutta "kävellä kadulla ilman mainoksia”. Vihkosessa tuodaan esille huoli erityisesti lapsista, jotka altistuvat mainosviestinnälle.

Eräs haastateltava pohti, kuinka "kauheen surullista" on, että "ihan jo lapset on suojattomia" mainonnan edessä. Hän kokee, ettei hänen tehtävänsä voi olla kuluttaminen ja hyvinvointiyhteiskunnan ylläpito:

H: "[--] ei musta mun tehtävä oo niinku kuluttaa sillä lailla että me saahaan oletettua hyvin-, hyvinvointia tai talouskasvua, [--]. Musta siinä ihminen myöskin objektivoidaan, [--] se ei oo mun tehtävä, [naurahtaen] se on ihan suuri taakka[?] jos mun pitäs niinku huolehtia siitä että, [--]yhteiskunta pysyy pystyssä tai [naurahdellen] hyvinvointivaltio pysyy pystyssä. Sii-, siihenhän vedotaan -"

Kestävyystutkijat Maria Joutsenvirta ja Arto O. Salonen (2020) kirjoittavat laajasti elämän rikkaudesta, uudenlaisesta vauraudesta. Heidän mukaansa hegemoninen näkemys hyvinvoinnin tavoittelusta on kytketty tiukasti rahaan ja rahatalouteen: "Tyytyväinen kansalainen, joka ei halua lisää materiaalista hyvää, muodostaa uhan jatkuvan talouskasvun varaan viritetylle hyvinvointiyhteiskunnalle." (Joutsenvirta \& Salonen 2020, 122.) Kohtuuspamfletin takakannessa lukeekin suurin kirjaimin: "Kohtuus on vaarallista".

\section{Ihmistenvälisyys}

Kohtuus vaarassa -ryhmälle kasvokkaisten kohtaamisten merkitys on suuri, ja tapaamisten tärkeyttä on pohdittu monissa kokous- ja taukokeskusteluissa. Ryhmällä on tapana kokoustaa noin kerran kuukaudessa, parissa. Ydinryhmäläisten välillä vallitsee kokemukseni mukaan vahva yhteenkuuluvuus. Toki myös kriittisiä äänenpainoja kuuluu satunnaisesti, eivätkä mielipiteet aina ole täysin yhteneväisiä. Solidaarisuus on kuitenkin vahvaa, ja retkillä ja seminaareissa muodostuu yhteishenkeä. Esimerkiksi vuoden 2019 seminaarissa, yli 100 osallistujan tapahtumassa, huolehdittiin toisista kyselemällä kyydeistä ja majoituksista, sadevaatteista ja yöunten laadusta. Toisilleen ennalta vieraat henkilöt liittyivät yhteen, ja heidän välilleen rakentui havaintojeni mukaan yllättävän nopeasti hyvinkin mutkattomia suhteita.

Yhteyden tunne ryhmään on tärkeä Kohtuus vaarassa -ryhmän ytimessä ja sen liepeillä. Eräs aktiivi palasi omiin kokemuksiinsa ryhmän uutena jäsenenä. Hän oli tullut mukaan toimintaan myönteisten ryhmätyökokemusten kannustamana. Hän muisteli jännittäneensä, kuinka hänen ajatuksensa otetaan vastaan. Vastaanotto oli myönteinen, mutta viime aikoina pulmalliselta oli alkanut tuntua oma tietämättömyys: erilaisissa tilanteissa mainitaan henkilöitä, käsitteitä ja kirjoja, joita ryhmäläisten oletetaan tuntevan. Hän ei tunnista ja tiedä tätä kaikkea, minkä seurauksena hän on kokenut toisinaan ulkopuolisuutta.

Toinen haastateltava navigoi lähipiirin mielipiteiden muodostamassa karikossa. Aiemmin haastattelun aikana hän oli kertonut läheisistään, joista jotkut olivat myötämielisiä hänen ajatuksilleen, jotkut eivät. Kun myöhemmin kysyin ulkoapäin tulevista 


\section{YHTEYDEN TUNNE RYHMÄ̈̈N ON TÄRKEÄ.}

paineista, hän kertoi "lietsovansa" itsessään rohkeutta ja "ympärilleen vilkuilemattomuutta". Vastakkaisten kantojen ilmaiseminen on kuitenkin tehtävä varoen, vaikka omasta kannastaan pitääkin kiinni:

H: "Minussa on kuitenkin se vaikuttamisen tarve. Kun minusta se on välittämistä, potkia eteenpäin. Niin kuin näitäkin läheisiä. Koitan mutta niinkun. Mutta niin. Se on perusongelma on justiin, että ei halua, jos väärin toimii, niin aiheuttaa hallaa vaan. Että milloin on hyvä avata suu ja miten. Tää on se [naurahtaen] elämän suurimpia kysymyksiä! Jos itelle on, vakuuttunut, jostakin ja jotakin on oivaltanut; joku sano, että jos on jotakin oivaltanut, niin on vaikea päästä enää siihen viattomuuden tilaan. [--] Minusta se on kyynistä, jos vaan jää siihen, mielessäni koko ajan kritisoin, enkä suutani avaa. Ja tässä tullaan justiin siihen kansalaisvaikuttamiseen. [--] Jeesuskin kehotti jättämään perheensä. Minusta voi Raamatusta asti löytää tukea sille, että jos on oivaltanut jotakin, mikä ei ole hyväksi vain minulle, [hieman huudahtaen] vaan koko ihmiskunnalle [--]"

Erään haastateltavan mukaan sen, joka "hoksaa" ja alkaa tiedostaa asioita, pitää " uskaltautua sitte, ruveta keräämään porukkaa tai sanoa ääneen”. Hän kertoikin ottavansa puheeksi ystäviensä kanssa, sopivissa hetkissä, kohtuustapahtumissa kuulemaansa ja oppimaansa. Hän kuvasi sen olevan "tämmöstä niinku ihan minitason vuorovaikutusta".

Kymmenvuotisseminaarissa kohtuusliikkeen tapaa vaikuttaa lähdettiin sanoittamaan postilaatikkokohtaamisten avulla. Idea virisi kasvunjälkeistä taloutta tutkivan Eeva Houtbeckersin puheenvuorosta paneelikeskustelussa. Hän oli osallistunut seminaariin, jossa professori Philomena Essed oli kertonut, kuinka rasistisiin puheisiin tulisi arjessa puuttua: jos naapuri aamulla postilaatikolla jutustellessa sanoo jotakin rasistista, antirasistisen toimijan tulee todeta olevansa eri mieltä (ks. Houtbeckers 2020).
Toimintatapa muistui seminaariosallistujien mieliin pitkin tapahtumaa, ja havaintojeni mukaan se tuntui monista osallistujista mielekkäältä tavalta toimia; kohtuuden viestiä tulisi jakaa samalla tavalla, nimenomaan arjen kohtaamisissa.

Haastatteluissa taas pohdittiin toiminnan luonnetta jopa kriittisessä sävyssä: miksemme pyri vaikuttamaan voimakkaammin? Eräs napautti:

H: "Tällaisena se on jutustelukerho. Tarpeellinen pohtimisfoorumi."

K: "Tarpeellinen kenelle? Niille itselle, toimijoille?"

K: "Meille itselle."

Kohtuus vaarassa -toimijoista monet ovat akateemisesti koulutettuja, ja ydinjoukossa on eläkeiässä olevia tai sitä lähestyviä aktiiveja. Muutama haastateltu toikin esille ikänsä ja viittasi taustaansa, kun otin puheeksi liikkeen toimintatavat. He laittavat toivonsa nuoriin, kuten Elokapina-ryhmään ja kouluikäisiin ilmastolakkoilijoihin. Itseään he pitivät sopimattomina radikaaliin toimintaan. Haastateltavat siis olettavat, että radikaalit aktiot ovat tehokas tapa vaikuttaa. Kokoustaminen, retket ja seminaarit eivät vaikuta täysin täyttävän kaikkien osallistujien toiveita - mutta itse ei olla halukkaita kiipeämään "piipun päälle protestoimaan", kuten haastateltava lausahti.

Kokoontumisia kritisoitiin muutamissa haastatteluissa samanmielisten kokoontumisiksi: kohtuuden idean jo omaksuneet ihmiset keskustelevat keskenään, mikä on muutoksen kannalta hedelmätöntä. Toisille ja osin samoillekin aktiiveille tapaamiset näyttäytyivät kuitenkin myös keitaana. Kokouksista haetaan ja saadaan kontakteja, tunnetaan kuulumista ryhmään ja päästään osaksi yhteisöä. Solidaarisuus kuuluu aineistossa esimerkiksi siinä, kuinka lohduttavaa on tietää, että on samalla tavalla ajattelevia ihmisiä. Yksi haastateltu viittasi kulutusta korostaviin, vastakkaisiin mielipiteisiin:

H: "[--] tätähän rekisteröi koko ajan, koko ajan kuulen ja näen. Jatkuvasti. Sen kanssa on elettävä, mutta sitten siihen just helpottaa, kun on tämmösiä keitaita, niinkun kohtuusporukka."

Myös aikuisten, ei ainoastaan lasten ja nuorten, on voitava löytää tapoja purkaa ympäristöahdistustaan 
(Pihkala 2017; Pihkala 2018). Kohtuusryhmässä tähän avautuu mahdollisuus. Lisäksi kohtuullisemmin eläminen jo itsessään lievittää ympäristöahdistusta.

H: ”Se lievittää ympäristöahdistusta myös, että -elämäntapa enemmän sopusoinnussa sen kanssa, mitkä on omat ihanteet. Että tietää, ettei kuluta ihan maksimimäärässä sitten luonnonvaroja. Jostain vapaaehtoisesti vähentää. Plus että, jos sitten hakeutuu samanhenkisten ihmisten kanssa yhteistyöhön, niin sehän on oikein mukavaa [naurahtaa]."

"Keitaalta" saa tietoa, ja se tarjoaa myös hengähdyspaikan. Kokoontumisten jälkeen liikkeen aktiivit ovat virkistyneitä ja valmiimpia viemään eteenpäin kohtuullisen elämäntavan sanomaa. Tulkintani mukaan juuri tämä - solumainen toiminta - on ryhmän tärkein vaikuttamiskeino. Yksin toimiminen voidaan täten nähdä lopulta yhdessä tekemisenä.

\section{KOHTUUSLIIKE KASVATTAJANA}

Olen tarkastellut pohjoiskarjalaista Kohtuus vaarassa -ryhmää ekososiaalisena sivistäjänä vastuullisuuden, kohtuullisuuden ja ihmistenvälisyyden näkökulmista. Pidän jaottelua keskeisenä teoreettisena jäsennyksenä ekososiaalisen sivistyksen olemuksesta, mitä "testaaminen" empiirisellä aineistolla vahvisti (ks. Schreier 2014, 5).

Kohtuus vaarassa -liikkeessä monien nykyisten ongelmien nähdään kytkeytyvän toisiinsa kasvunpakon linkittäminä. Yksittäisten ongelmien atomistisen käsittelyn sijaan pöydälle voidaan nostaa kimppu toisiinsa kietoutuvia kysymyksiä; ekologiset haitat kietoutuvat muun muassa sosiaalisen epäoikeudenmukaisuuden haasteisiin (ks. Kallis 2011). Ryhmälle on ominaista tavoitella laajan kokonaisuuden hahmottamista, ja ratkaisun avaimena nähdään kohtuullisuus. Sille - tai lyhyemmin ilmaistuna 'kohtuudelle' - haetaan ryhmässä jatkuvasti määrittelyjä. 'Kohtuudella' viitataan havaintojeni mukaan laajasti kokonaiseen tapaan olla ja elää. Samansuuntaisia päätelmiä on tehnyt kohtuullistajia haastatellut Kuosmanen (2010) pro gradu -tutkielmassaan. Ylenpalttisen kulutuksen, materiaalisen yltäkylläisyyden ja uuvuttavan työelämän tilalle toivotaan hyviä sosiaalisia suhteita ja mielekästä vähään tyytymistä.

Pohjoiskarjalaiset kohtuustoimijat arvostavat kasvokkaisia kohtaamisia. He hakevat ryhmästä vertaista seuraa ja tietoa. Lisäksi yhdessä toimiminen liennyttää negatiivisia ympäristötunteita, kuten muun muassa Pihkalakin $(2017,239-240)$ on todennut. Useat haastateltavat toivat esille, kuinka hyvältä tuntuu olla samoin ajattelevien seurassa ja päästä keskustelemaan itselle tärkeistä aiheista. Ryhmässä koettiin olevan paljon tietämystä, ja jopa ne, joilla on paljon tietoa monista kohtuusliikkeessä puhutuista aiheista, pitivät muiden kanssa juttelemista arvokkaana.

Kansalaisaktivismia tutkineet Teppo Eskelinen, Tiina Seppälä ja Sanna Ryynänen $(2019,76)$ esittävät, että kaikki kansalaisosallistuminen ei ole rohkeaa eikä radikaalia, vaan rohkeus ilmenee niissä hetkissä, kun totuttua rikotaan. Kohtuus vaarassa -ryhmä toimii tavallaan juuri näin: se kyseenalaistaa valtavirta-ajattelua ja esittää hyvinkin radikaaleja vaatimuksia, kuten rajoituksia mainontaan. Ryhmän tapa toimia ei kuitenkaan koettele lain rajoja kansalaistottelemattomuuden hengessä. Sen toimintamuodot, luennot ja seminaarit, ovat perinteisiä ja tuttuja, mutta sen esittämät vaatimukset radikaaleja, ja ne koskevat koko ylikuluttavaa länsimaista elämäntapaa. Liike asettuu näin sekä maltillisen että rohkean kansalaistoiminnan kentille.

Keskeinen päätelmäni on, että liike toimii solumaisesti: jokainen jäsen vie kohtuuden sanomaa eteenpäin omissa verkostoissaan. Vaikka toimintaa on kritisoitu samanmielisten kokoontumisiksi, seminaarien suuret osallistujamäärät ja toiminnan laajeneminen muille paikkakunnille kertovat liikkeen kasvusta.

On mahdotonta liioitella ekologista uhkaa, joka leijuu ihmiskunnan yllä (Foster, Clark ja York 2010b, 151). Uhka on konkretisoitunut tai ainakin konkretisoitumassa, ja tutkijat ovat esittäneet huolensa järjestäytyneiden yhteiskuntien säilymisestä, mikäli ilmasto jatkaa lämpenemistään (ks. esim. Steffen ym. 2018, 8257-8258). Myös monet kansalaisliikkeet vaativat tehokkaampia ilmastotoimia ja pyrkivät muuttamaan vallitsevaa talousajattelua.

Globaalien ekokriisien aikakaudella on tarpeen uudistaa sekä sivistyskäsitys että näkemys kasvatuksesta. Kasvatuksen on aiemmin ajateltu pikemminkin 
toisintavan ja ylläpitävän hegemoniaa, siirtävän tiettyjä ajattelumalleja sukupolvelta toiselle. Nyt sen tulee toimia juuri toisin: kannustaa kyseenalaistamaan ja haastamaan aiempia toimintatapoja. (Salonen \& Joutsenvirta 2018, 89; Sivenius, Värri \& Pulkki 2018, 102-103; Värri 2018, 28, 37-39.)

Kansalaisliike voi tarjota uudistavalle oppimiselle hyvän ympäristön. Hallitsevia rakenteita kyseenalaistava toiminta, jossa pyritään keksimään uutta (ks. Bäcklund, Häkli \& Schulman 2017, 254), haastaa toimijoiden ajattelua ja kehittää heidän taitojaan osallistua esimerkiksi kunnalliseen päätöksentekoon. Emansipatorisen ympäristökasvatuksen hengessä toimitaan ja opitaan yhteisöllisesti, tavoitellen muutosta havaittuihin epäkohtiin (Silva \& Laird 2017, 180-182).
Muun muassa kaupunkiaktivismia on tutkittu aikuiskasvatustieteellisestä näkökulmasta, mutta kansalaistoiminnan kentällä on monia muitakin toimintamuotoja ja -konteksteja, joita tulisi tutkia ekososiaalisen tai planetaarisen sivistyksen mahdollistajina ja tuottajina. Kulutuskriittiset kansalaisliikkeet, kuten Kohtuus vaarassa -ryhmä, voivat toimia uudistavina aikuiskasvattajina.

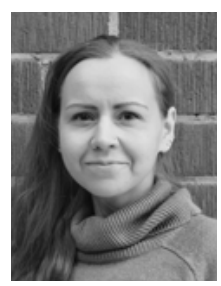

\section{ERJA LAAKKONEN}

KT, FM, vapaa tutkija, tuntiopettaja Itä-Suomen yliopisto

(D) https://orcid.org/0000-00030194-4014

\section{LÄHTEET}

Aho, M. (2015). Miten kaikki alkoikaan. Teoksessa T. Linjama \& P. Kainulainen (toim.) Kohtuus vaarassa: onnen aikoja rajallisella planeetalla? Joensuu: Kirjokansi, 11-12.

Aho, M. (2019). Vaarallista kohtuutta. Teoksessa T. Linjama, M. Aho, P. Kainulainen \& R. Simola (toim.) Kohtuuspamfletti. Elonkirjo edellä. Helsinki: Into, 168-169.

Alaja, A. (2011). Mikä ihmeen degrowth? Johdatus kasvukritiikin uuteen aaltoon. Kalevi Sorsa säätiön julkaisuja 4/2011. Helsinki: Kalevi Sorsa säätiö.

Alexander, U. \& Ussher, S. (2012). The Voluntary Simplicity Movement: A multi-national survey analysis in theoretical context. Journal of Consumer Culture, 12(1), 66-86. https://doi. org/10.1177/1469540512444019

Bäcklund, P., Häkli, J. \& Schulman, H. (2017). Lukijalle: kansalaisosallistumisen muuttuva kenttä. Teoksessa P. Bäcklund, J. Häkli \& H. Schulman (toim.) Kansalaiset kaupunkia kehittämässä. Tampere: Tampere University Press, 5-14.

Demaria, F., Schneider, F., Sekulova \& F., Martinez-Alier, J. (2013). What is Degrowth? From an Activist Slogan to a Social Movement. Environmental Values, 22(2), 191-215. https://doi.org/10.3197/09632711 $3 \times 13581561725194$

Eskelinen, T., Seppälä, T. \& Ryynänen, S. (2019). Kansalaisrohkeus: Tottelemattomia yksilöitä, yhteisöjä, tutkijoita. Sosiaalipedagoginen aikakauskirja, 20, 73-84.

Finto. Sanasto- ja ontologiapalvelu. Kohtuutalous: http:// www.yso.fi/onto/keko/p197
Foster, J., Clark, B., \& York, R. (2010a). Introduction. A rift in earth and time. Teoksessa J. B. Foster, B. Clark \& R. York (toim.) The Ecological Rift: Capitalism's War on the Earth. New York: NYU Press, 13-49.

Foster, J., Clark, B., \& York, R. (2010b). The planetary moment of truth. Teoksessa J. B. Foster, B. Clark \& R. York (toim.) The Ecological Rift: Capitalism's War on the Earth. New York: NYU Press, 151-166.

Heikkinen, A. \& Harju, A. (2016). Introduction: Why adult education and planetary condition? Teoksessa A. Heikkinen \& A. Harju (toim.) Adult Education and the Planetary Condition. Helsinki: Finnish Adult Education Association, 6-13.

Hirvilammi, T. (2015). Kestävän hyvinvoinnin jäljillä. Ekologisten kysymysten integroiminen hyvinvointitutkimukseen. Sosiaali- ja terveysturvan tutkimuksia 136. Helsinki: Kelan tutkimusosasto.

Houtbeckers, E. (2020). Degrowth, it's time to get real - Reflections on the importance of everyday encounters. https://eevahoutbeckers.fi/2020/06/08/ degrwoth-its-time-to-get-real (10.9.2020).

Husso, S. (2017). Kohtuullinen utopia. Eettisen itsen luominen kasvukriittisen yhteiskunnallisen liikkeen teksteissä. Sosiologia, 54(2), 167-182.

Ilmonen, K. (1998). Uudet ja vanhat yhteiskunnalliset liikkeet. Teoksessa K. Ilmonen \& M. Siisiäinen (toim.) Uudet ja vanhat liikkeet. Tampere: Vastapaino, $15-42$.

Ilmonen, K. \& Siisiäinen, M. (1998). Johdanto. Teoksessa K. Ilmonen \& M. Siisiäinen (toim.) Uudet ja vanhat liikkeet. Tampere: Vastapaino, 7-14. 
Ioncică, D.-E. \& Petrescu, E.-C. (2016). Slow living and the green economy. The Journal of Philosophical Economics, IX(2), 85-104.

Jarvis, H. (2017). Sharing, togetherness and intentional degrowth. Progress in Human Geography, 43(2), 256 275. https://doi.org/10.1177/0309132517746519

Joutsenvirta, M. \& Salonen, A. O. (2020). Sivistys vaurautena. Radikaalisti, mutta lempeästi kohti kestävää yhteiskuntaa. Helsinki: Basam Books.

Juhila, K. (2020a). Koodaaminen. Teoksessa J. Vuori (toim.) Laadullisen tutkimuksen verkkokäsikirja. Tampere: Yhteiskuntatieteellinen tietoarkisto. https://www.fsd.tuni.fi/palvelut/menetelmaopetus (11.2.2021).

Juhila, K. (2020b). Teemoittelu. Teoksessa J. Vuori (toim.) Laadullisen tutkimuksen verkkokäsikirja. Tampere: Yhteiskuntatieteellinen tietoarkisto. https://www.fsd. tuni.fi/palvelut/menetelmaopetus (30.3.2021).

Kallis, G. (2011). In defence of degrowth. Ecological Economics, 70(5), 873-880. https://doi. org/10.1016/j.ecolecon.2010.12.007

Kohtuusliike.fi: https://www.kohtuusliike.fi/tietoakohtuusliikkeesta.

Konttinen, E. \& Peltokoski, J. (2010). Liikkeet liikkeessä. Teoksessa E. Konttinen \& J. Peltokoski (toim.) Verkostojen liikettä. Jyväskylä: Jyväskylän yliopisto, 2-23.

Kristofferson, K., White, K. \& Peloza J. (2014). The Nature of Slacktivism: How the Social Observability of an Initial Act of Token Support Affects Subsequent Prosocial Action. The Journal of Consumer Research, 40(6), 1149-1166. https://doi.org/10.1086/674137

Kuosmanen, T. (2010). Kiire ja kohtuus. Kohtuuden kysymykset runsauden yhteiskunnassa. Pro gradu -tutkielma. Joensuu: Itä-Suomen yliopisto.

Laakkonen, E. (2019). Kohtuusliike kasvattaa ekososiaalisesti sivistyneitä aktiivisia kansalaisia. Teoksessa T. Linjama, M. Aho, P. Kainulainen \& R. Simola (toim.) Kohtuuspamfletti. Elonkirjo edellä. Helsinki: Into, 184-196.

Latva-Pukkila, A. (2015). Kasvunvara on käytetty. Kohtuutalouden ratkaisut. Helsinki: Suomen luonnonsuojeluliitto ry. https://www.sll.fi/app/ uploads/2018/10/Kohtuutalous_webversio.pdf

Lehtinen, A. A. (2019). Tahtomattaan radikaali: Talouden supistumisen maantiede. Terra: maantieteellinen aikakauskirja, 131(4), 235-246.

Lehtinen, A. A. (2014). Ympäristötoimintatutkimus. Teoksessa I. Massa (toim.) Polkuja yhteiskuntatieteelliseen ympäristötutkimukseen. Helsinki: Gaudeamus, 64-76.

Linna, T. (2017). Yhteiskunnallinen liike verkostona. Degrowth-liikkeen verkostomainen toiminta Suomessa. Pro gradu -tutkielma. Jyväskylä:
Jyväskylän yliopisto.

Martin, J., Maris, V. \& Simberloff, D. (2016). The need to respect nature and its limits challenges society and conservation science. Proceedings of the National Academy of Sciences of the United States of America, 113(22), 6105-6112.

Mezirow, J. (2009). An overview on transformative learning. In K. Illeris (ed.) Contemporary Theories of Learning: Learning Theorists in Their Own Words. London: Routledge, 90-105.

Metsola, L. (2016). Pelkoa, valtaa ja vapautta: entisten taistelijoiden parissa Namibiassa. Teoksessa J. Gould \& K. Uusihakala (toim.) Tutkija peilin edessä: Refleksiivisyys ja etnografinen tieto. Helsinki: Gaudeamus.

Mäenpää, P., Faehnle, M. \& Schulman, H. (2017). Kaupunkiaktivismi, jakamistalous ja neljäs sektori. Teoksessa P. Bäcklund, J. Häkli \& H. Schulman (toim.) Kansalaiset kaupunkia kehittämässä. Tampere: Tampere University Press, 239-259.

Mäenpää, P. \& Faehnle, M. (2021). Neljäs sektori Kuinka kaupunkiaktivismi haastaa hallinnon, muuttaa markkinat ja laajentaa demokratiaa. Tampere: Vastapaino.

Pihkala, P. (2017). Päin helvettiä? Ympäristöahdistus ja toivo. Helsinki: Kirjapaja.

Pihkala, P. (2018). Johdatus ympäristöahdistukseen. Ympäristöongelmien psyykkiset vaikutukset. Tieteessä tapahtuu, (36)6, 31-38.

Salonen, A. O. (2020). Planetaarinen sivistys on vastaus aikamme ongelmiin. UEF Puheenvuoroja. https:// blogs.uef.fi/puheenvuoroja/2020/01/30/planetaarinensivistys-on-vastaus-aikamme-ongelmiin (7.9.2020).

Salonen, A. O. \& Bardy, M. (2015). Ekososiaalinen sivistys herättää luottamusta tulevaisuuteen. Aikuiskasvatus, 35(1), 4-15. https://doi.org/10.33336/aik.94118

Salonen, A. O. \& Joutsenvirta, M. (2018). Vauraus ja sivistys yltäkylläisyyden ajan jälkeen. Aikuiskasvatus, 38(2), 84-101. https://doi.org/10.33336/aik.88331

Schreier, M. (2014). Qualitative content analysis. Teoksessa U. Flick (toim.) The SAGE handbook of qualitative data analysis. London: SAGE, 170-183. https://www.doi.org/10.4135/9781446282243

Silva, P. \& Laird, S. G. (2017). Adult education. Teoksessa A. Kudryavtsev \& M. E. Krasny (toim.) Urban Environmental Education Review. Cornell University Press: Ithaca, NY, 175-184.

Sivenius, A., Värri, V.-M. \& Pulkki, J. (2018). Ekologisemman sivistysajattelun haasteita aikamme teollistuneessa arvoympäristössä. Teoksessa H. Silvennoinen, M. Kalalahti \& J. Varjo (toim.) Koulutuksen lupaus ja koulutususko. Kasvatussosiologian vuosikirja II. Helsinki: Suomen kasvatustieteellinen seura, 101-125. 
Steffen, W., Rockström, J., Richardson, K., Lenton, T., Folke, C., Liverman, D., Summerhayes, C., Barnosky, A., Cornell, S., Crucifix, M., Donges, J., Fetzer, I., Lade, S., Scheffer, M., Winkelmann, R., \& Schellnhuber, H. (2018). Trajectories of the Earth system in the Anthropocene. Proceedings of the National Academy of Sciences - PNAS, 115(33), 8252-8259. https://doi.org/10.1073/ pnas. 1810141115

Stranius, L. (2009). Epämuodollinen kansalaistoiminta - järjestötoiminnasta kevytaktivismiin. Teoksessa T. Kankainen, H. Pessala, M. Siisiäinen, L. Stranius, H. Wass \& N. Wilhelmsson. Suomalaiset osallistujina: katsaus suomalaisen kansalaisvaikuttamisen tilaan ja tutkimukseen. Oikeusministeriön julkaisuja 2009:5. Helsinki: Oikeusministeriö, 138-169.

Stranius, L. (2010). Ympäristöliikkeen uudet haasteet. Teoksessa E. Konttinen \& J. Peltokoski (toim.) Verkostojen liikettä. Jyväskylä: Jyväskylän yliopisto, 80-101.

Sumner, J. (2003). New Directions for Adult and Continuing Education, (99), 39-45. https://doi. org/10.1002/ace. 108

Tolonen, T. \& Palmu, T. (2007). Etnografia, haastattelu ja (valta)positiot. Teoksessa S. Lappalainen, P. Hynninen, T. Kankkunen, E. Lahelma \& T. Tolonen (toim.) Etnografia metodologiana: Lähtökohtana koulutuksen tutkimus. Tampere: Vastapaino, 89-112.

Tracy S. J. (2010). Qualitative Quality: Eight “BigTent" Criteria for Excellent Qualitative Research. Qualitative Inquiry, 16(10), 837-851. https://www. doi.org/10.1177/1077800410383121

Trainer, T. (2015). The Degrowth Movement from the Perspective of the Simpler Way. Capitalism, Nature, Socialism, 26(2), 58-75. https://doi.org/10.1080/104 55752.2014 .987150

Tuomi, J. \& Sarajärvi, A. (2017). Sisällönanalyysi. Uudistettu laitos. Helsinki: Tammi.

Ulvila, Marko. (2018). Kohtuusliikkeen lyhyt historia. Elonkehä (4), 20-26.

Usher, R. (2008). Consuming Learning. Convergence, 21(1), 29-45.

Vuori, J. (2020). Laadullinen sisällönanalyysi. Teoksessa J. Vuori (toim.) Laadullisen tutkimuksen verkkokäsikirja. Tampere: Yhteiskuntatieteellinen tietoarkisto. https://www.fsd.tuni.fi/palvelut/menetelmaopetus (11.2.2021).

Värri, V.-M. (2011). Vastuu ihmisen mittana. Kasvatusteoreettisia ja filosofisia näköaloja ekologiselle sivistysprojektille. Tiedepolitiikka, (4), 27-38.

Värri, V.-M. (2018). Kasvatus ekokriisin aikakaudella. Tampere: Vastapaino.

\section{PAINETUT JA SÄHKÖISET AINEISTOLÄHTEET}

10 kohtuullista vaatimusta. Hyväksytty Kolilla 24.10.2009. http://www.kohtuusvaarassa.com/about

Kohtuusmanifesti. Aineksia vastuulliseen hallitusohjelmaan. (2011). Useita kirjoittajia.

Kohtuuspamfletti. Elonkirjo edellä. (2019). T. Linjama, M. Aho, P. Kainulainen \& R. Simola (toim.). Helsinki: Into.

Kainulainen, P. (2019). Luonnonsuojelu tarvitsee mystiikkaa. Teoksessa T. Linjama, M. Aho, P. \& R. Simola (toim.) Kohtuuspamfletti. Elonkirjo edellä. Helsinki: Into, 98-105.

Kohtuus vaarassa: onnen aikoja rajallisella planeetalla? 2015. Toimittaneet Topi Linjama \& Pauliina Kainulainen. Joensuu: Kirjokansi.

Kohtuus vaarassa -kanava yhteisöpalvelu YouTubessa. http://youtube.com/kohtuusvaarassa

Vadén, T. (2019.) Ylikulutuksen synnyt ja taudin parantaminen. Luentotallenne. https://www.youtube. com/watch?v=19oLOyAvU2s

Kohtuus vaarassa -sivusto. http://www.kohtuusvaarassa. com

Kohtuus vaarassa -sivu yhteisöpalvelu Facebookissa. https://www.facebook.com/KOHTUUSVAARASSA-142527782686 